УДК 902/904

https://doi.org/10.24852/2587-6112.2021.3.169.185

\title{
МАСТЕРСКАЯ БУЛГАРСКОГО РЕМЕСЛЕННИКА-МЕДНИКА НА РОЖДЕСТВЕНСКОМ ГОРОДИЩЕ В ПЕРМСКОМ КРАЕ
}

\author{
(C) 2021 г. Н.Б. Крыласова
}

В качестве подарка к юбилею Ф.Ш.Хузина в статье представлены основные данные о значимом для средневековой археологии Волго-Камского региона открытии медницкой мастерской на Рождественском городище - торгово-ремесленной фактории булгар в Пермском крае. Мастерская была основана в XII в. медником, переселившимся из Волжской Булгарии, и продолжала функционировать до второй половины XIII века. Она занимала обширную постройку каркасной-столбовой конструкции площадью более 200 кв. м, которая была разделена перегородками на хозяйственное, жилое и производственное помещения, где ремесленник и работал, и проживал со своей семьей. Полученные в мастерской богатые материалы (в основном, отходы производства - медные сплески, недокованные пластины, обрезки пластин, пластинчатые заклепки на всех стадиях изготовления и пр.) позволяют в полной мере проследить технологию медницкого дела, представить ассортимент продукции, производимой медником (котлы, предметы быта, украшения, проволока), частично - набор инструментов, практически аналогичных кузнечным. Сопутствующие материалы бытового и хозяйственного назначения свидетельствуют о высоком уровне жизни ремесленника, о его грамотности (находка стилоса). Несомненно, булгарские мастера, поселившиеся на Рождественском городище, известном по арабским источникам как городок Афкула, не только обеспечивали местное население ремесленной продукцией, но и способствовали развитию здесь городской культуры.

Ключевые слова: археология, Пермский край, эпоха средневековья, ремесло, медницкое дело, мастерская медника

\section{BOLGAR COPPERSMITH'S WORKSHOP AT ROZHDESTVENSK HILLFORT IN PERM KRAI ${ }^{2}$}

\section{N. B. Krylasova}

AIn order to commemorate F. Sh. Huzin's anniversary, the author present the main information about a significant event in the medieval archaeology of the Volga-Kama region - the important discovery of a coppersmith's workshop at Rozhdestvensk hillfort, a trading post of Bolgar craftsmen in Perm Krai. The workshop was founded in the $12^{\text {th }}$ century by a coppersmith who had moved from Volga Bolgaria. It remained active until the second half of the $13^{\text {th }}$ century. Located in a spacious frame-and- post structure with an area of over 200 square meters, it was subdivided by partitions into a housekeeping area, living quarters and the workshop. In this building, the coppersmith both worked and lived with his family. An analysis of the abundant material from the workshop (for the most part, production wastes - copper splashes, half-finished plates, plate clips, plate studs from all stages of production, etc.) makes one fully traced the technology of the coppersmith's craft, as well as the variety of produced articles (cauldrons, household items, decorations, wire) and, to a certain extent, the set of tools almost identical to that of a blacksmith. The discovered accompanying everyday and household items reveal that the standard of the craftsman's living was rather high and that he was literate (a stylos was found at the site). Undoubtedly, Bolgar craftsmen who came to dwell at the Rozhdestvensk hillfort (known in Arabic sources as the town of Afkula) did not only supply the locals with their production, but also promoted culture and raised living standards in the area.

Keywords: archaeology, Perm Krai, the Middle Ages, craft, coppersmith's craft, coppersmith's workshop.

Работа выполнена в рамках государственного задания, номер государственной регистрации темы AАAА-А19-119032590066-2; при поддержке Министерства образования и науки Пермского края, соглашение № C-26/1192 от 19.12.2019 г. и при поддержке Российского фонда фундаментальных исследований (РФФИ), проект №20-49-590001 p_a_Пермский край «Средневековое ювелирное наследие Пермского края: стилистические и химико-технологические особенности».

The study was carried out as part of State Assignment under the state registration topic No. AAAA-A19-119032590066-2; supported by the Ministry of Culture and Science of the Perm Region, agreement № C-26/1192 dated December 19, 2019 and by the Russian Fund for Basic Research (RFBR), project №20-49-590001p_a the Perm Krai “Jewellery Heritage from the Middle Ages in the Perm Region: Stylistic and Chemico-Technological Features". 
Ф.Ш. Хузин отмечает роль торговых путей, в том числе Камского, не только в движении товаров, но и новых идей, полезной информации, проникавшей в разные регионы посредством купцов или, в некоторых случаях, мастеров определенных видов производства (напр., ювелиров, стеклоделов, гончаров и т. д.) (Хузин, 2018, с. 53).

Камский торговый путь шел на Север и в Западную Сибирь по землям с финно-угорским населением (Белавин, 1999; Белавин, 2000). Развитие системы дальних и ближних торговых путей, в особенности путей дальней транзитной торговли, стало основным фактором процесса урбанизации в землях приуральских финно-угров (Белавин, 2001). Катализатором этого процесса была Волжская Булгария, проведение основных торговых операций и контроль которой за региональной торговлей осуществлялись через систему торгово-ремесленных городков-факторий (Белавин, 2019, с. 120).

В Пермском Предуралье есть несколько крупных поселений протогородского типа, особое место среди которых занимает Рождественское городище X-XIV вв. («касаба Афкула», по письменным источникам (Белавин, Крыласова, 2017)), выделявшееся среди других за счет того, что изначально строилось и функционировало как торгово-ремесленная фактория Волжской Булгарии (Белавин, 2019, с. 124). За длительный период исследования городища на нем выделены остатки многочисленных мастерских (металлургических, гончарных, косторезных). На присутствие в составе населения города булгарских ремесленников однозначно указывает наличие гончарных горнов булгарского типа (Белавин, Крыласова, 2009, с. 13). В металлургической мастерской, изученной в 2008-2009 гг. в югозападной части площадки городища, высокий процент булгарской посуды типа Джукетау может служить индикатором исходной территории, откуда переселился работавший здесь ремесленник (Крыласова, 2008, с. 147).

В 2018-2019 гг. на раскопе VIII в северовосточной части площадки городища неподалеку от вала была открыта и в значительной степени изучена мастерская медника. Прежде о наличии собственного медницкого дела в Пермском Предуралье существовали лишь предположения, основанные на анализе готовой продукции (Руденко, 2000, с. 59).

Мастерская представляла собой бревенчатую постройку, ширина которой составляла 12 м, длина изученной части - 18 м, площадь
$>216 \mathrm{M}^{2}$. Она была построена в каркасностолбовой технике - вдоль стен были врыты вертикальные столбы, между ними горизонтально заложены бревна, образующие стены (рис. 1/A). Двускатная кровля также опиралась на столбы, установленные тремя рядами вдоль условной оси постройки (рис. 1/Б, $\mathrm{B}$, Г). Обширное пространство мастерской разделялось перегородками на три помещения (рис. 1/Д, Е). Наибольшее из них площадью $120 \mathrm{~m}^{2}$ располагалось в восточной части постройки, и, судя по составу находок, имело в основном производственное назначение. Центральное помещение постройки площадью $72 \mathrm{M}^{2}$ содержало больше находок бытового характера, хотя и здесь представлено множество материалов, связанных с производственной деятельностью (преимущественно кузнечным и медницким делом). Западная часть постройки почти полностью осталась за пределами раскопа. Конструктивно постройка не отличается от жилищ, и, судя по значительному количеству находок бытового характера (хозяйственные орудия, орудия домашнего производства, фрагменты керамической посуды, детали костюма и украшения и пр.), не исключено, что мастерская занимала часть дома, где проживал мастер с семьей.

В интерьере мастерской выделены столбовые конструкции из кольев небольшого диаметра в основании пристенной лавки шириной 1 м с западной стороны от восточной перегородки, а также нар шириной 2 м с западной стороны от западной перегородки, разделявшей постройку (рис. 1: Ж, 3). В изученной части мастерской исследовано 8 ям и 3 очага. Одна из ям (№ 4) представляла собой основание печи-каменки, которую можно интерпретировать как кузнечный горн. Здесь же могли производиться ковка меди и разные операции с листовой медью, осуществляемые под нагревом. Три большие ямы (№ 6, 7, 8) первоначально функционировали как ямы-кладовки, позже были переоборудованы в ямы-nодпечья, над которыми на помосте располагались основания печей. В одной из ям (№ 9) в небольшом углублении на деревянном настиле была установлена бочка, вероятно, служившая в качестве емкости для воды, используемой для технических нужд, о чем свидетельствуют находки в яме медных пластин и прочих свидетельств медницкого производства, в особенности по контуру древесного тлена от стенок бочки (рис. 1).

В культурном слое мастерской обнаружены многочисленные обломки металлургиче- 


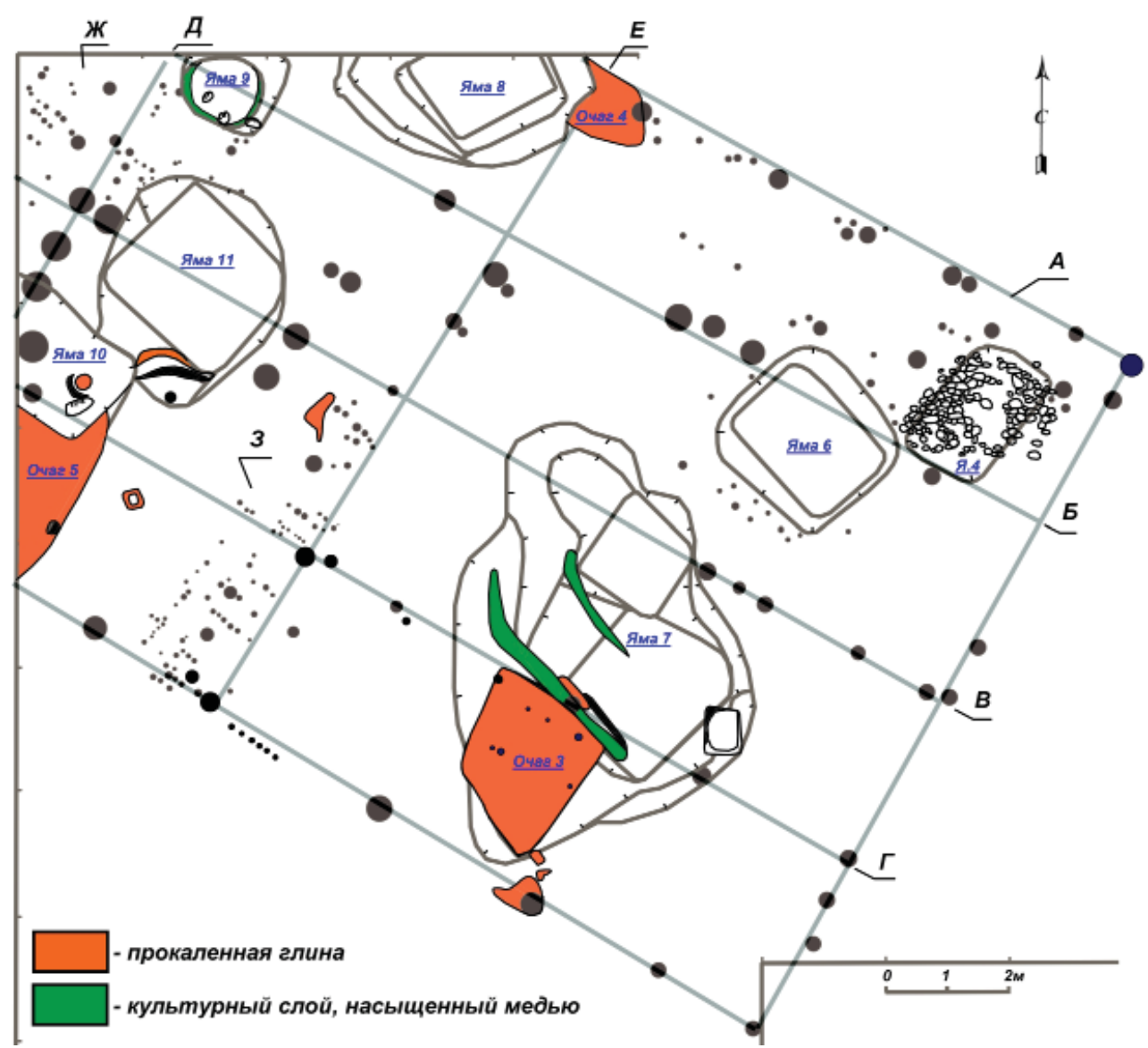

Рис. 1. План мастерской медника (Рождественское городище, раскоп VIII 2018-2019 гг.): А - периметр стен; Б, В, Г - линии опорных столбов двускатной кровли; Д, Е - линии основания перегородок; Ж, 3 - опоры нар Fig. 1. Plan of a coppersmith's workshop (Rozhdestvensk hillfort, excavation VIII of 2018-2019): A - a perimeter of the walls; Б, В, Г- lines of the support pillars of the gable roof; Д, E - lines of the base of partitions;

Ж, 3 - supports of bunk beds

ских печей, которых было как минимум две. С остатками одной из них связаны фрагменты толстых прокаленных глинобитных стенок с заметным изгибом на внутренней поверхности, где наблюдались следы стекловидного шлака. Вторая печь была сложена из толстых стенок преимущественно булгарских гончарных сосудов, которые были уложены вплотную друг к другу и с внутренней стороны скреплены стекловидным шлаком. За два года собрано 64 фрагмента этой печи (рис. 2: А). Подробный анализ производственных сооружений и реконструкция особенностей их функционирования еще предстоят, а на основании полученных вещевых материалов уже можно сделать предварительные выводы о деятельности ремесленника.

Полуфабрикатами для медницкого, литейного, и, возможно, ювелирного производства служили слитки серебра, олова, меди и сплавов на ее основе (рис. 2: Б).

Культурный слой в пределах мастерской был насыщен медными предметами, в некоторых местах возле производственных объектов он имел отчетливый зеленый оттенок. Из таких предметов значительную серию составляли капли, сплески металла и обрубленные литники. А наиболее массово представлены разнообразные фрагменты пластин, представляющие собой отходы производства и полуфабрикаты изделий (1195 экз.). Анализ этих материалов позволяет выделить основные этапы производственного процесса.

Среди сплесков представлено несколько достаточно крупных «лепешек», полученных при выливании расплавленной меди на плоскую поверхность (рис. 2: В), они могли служить заготовками, из которых в дальнейшем путем горячей ковки получали пластины. В коллекции имеются не до конца раскованные толстые пластины (рис. 2: Г), а также фрагменты литых листов со следами проковки с краю, очевидно, обрезки, оставшиеся после выкройки кованых пластин.

Основной продукцией медника, очевидно, являлась посуда, и в первую очередь - медные котлы, которые пользовались большой популярностью у местного финно-угорского населения. Технология изготовления медных котлов достаточно хорошо изучена, в том 


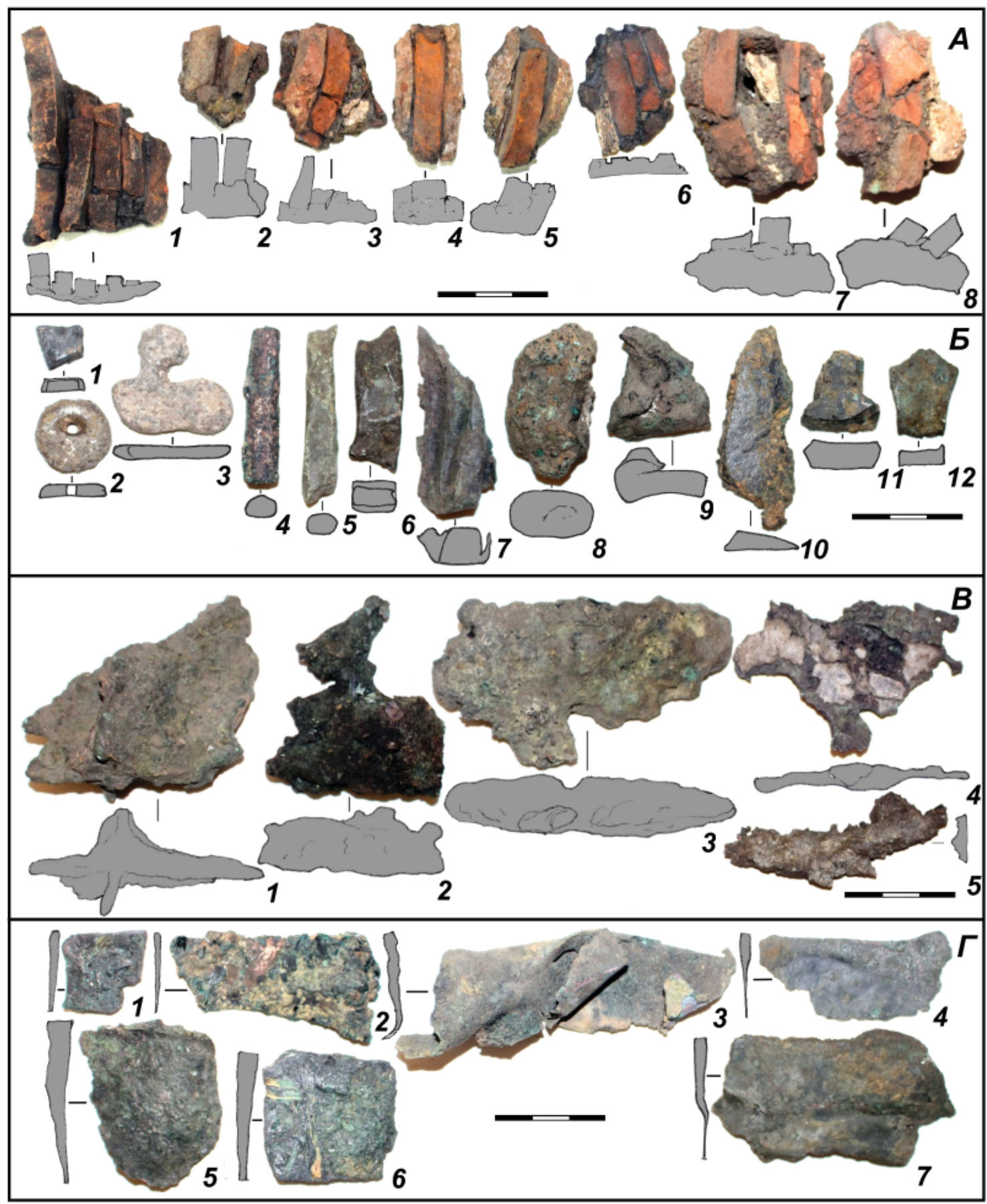

Рис. 2. А - примеры фрагментов печи, сложенной из стенок керамических сосудов; Б - слитки (1 - серебро, 2-3 - олово, 4-12 - медь, сплавы на основе меди); В - примеры медных «сплесков»;

$\Gamma$ - примеры не докованных медных пластин

Fig. 2. A - examples of fragments of a furnace built from the walls of ceramic vessels; 5 - ingots $(1-$ silver, 2-3 - tin, 4-12 - copper, copper-based alloys); B - examples of copper "splashes"; $\Gamma$ - Examples of unfinished copper plates

числе экспериментально (Кузьминых, Семыкин, 2006, с. 271).

Прокованные пластины раскраивались. После, судя по заворотам кромок, производилась посадка металла при изготовлении бортика (венчика) сосуда (Руденко, 2000, с. 17). Механическая сборка медной посуды производилась с помощью зубчатых кромок «в расщеп» или «в зубец» - края соединяемых металлических листов нарезались железны- ми ножницами по металлу или нарубались зубилом на глубину 0,5-0,7 см при примерно равных промежутках (Руденко, 2000, с. 15; Кузьминых, Семыкин, 2006, с. 271). Нарезанные «зубцы» заготовок разводились через один в противоположные стороны, зубчатые края совмещали, прижимали и проковывали. К.А. Руденко отмечает, что в ХІ в. осуществлялось надрезание двух стыкующихся кромок. С XII в. распространился способ, 


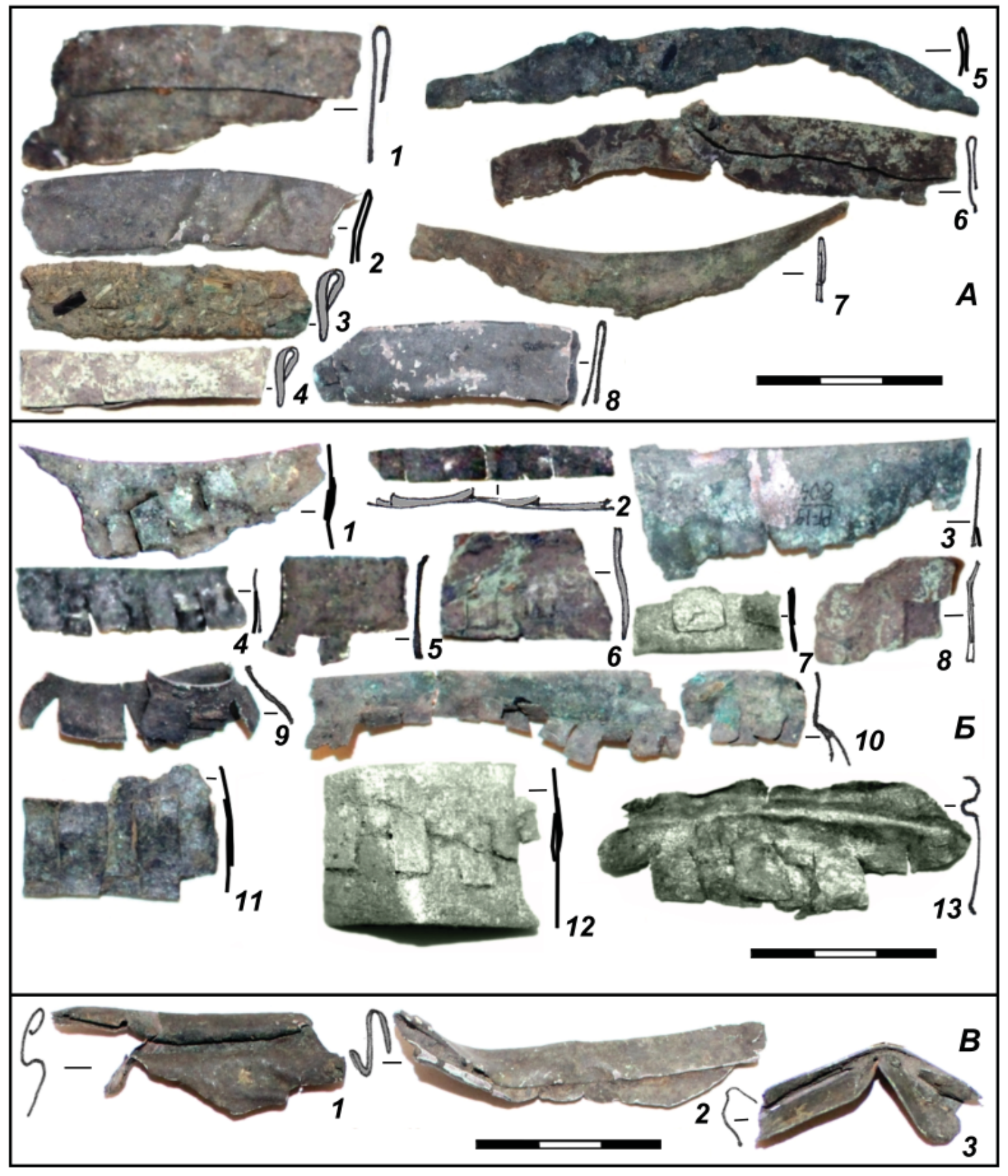

Рис. 3. А - примеры фрагментов венчиков котлов; Б - примеры пластин с зубцами; В - примеры пластин для фальцевого соединения

Fig. 3. A - examples of fragments of cauldrons rims; Б - examples of plates with teeth; B - examples of seam plates

при котором надрезался только один край, а у второй заготовки край утончался проковкой (Руденко, 2000, с. 16-17), чтобы он плотнее садился между зубцами. В сочетании со сборкой «в зубец» использовались фальцевые соединения, при которых две пластины скреплялись отогнутыми кромками, плотно прижатыми друг к другу (Руденко, 2000, с. 17). Сборка производилась на цилиндрических деревянных оправках. После соединения зубцов по всей линии их после небольшого нагрева разгибали и проковывали, затем корпус подправлялся выколоткой и посадкой металла. После плотной проковки образовы- вался прочный шов, который для герметичности мог дополнительно пропаиваться (Кузьминых, Семыкин, 2006, с. 271). Аналогично присоединялось днище, но в этом случае на заготовке дна делался припуск на высоту борта (Руденко, 2000, с. 17).

В коллекции, собранной в пределах мастерской, выделяются фрагменты венчиков медных котлов с завернутой кромкой, иногда с проложенной внутри пластиной (рис. 3/A), обрезки пластин с фрагментами швов «в зубец» и пластин с нарезанными зубцами, которые не подвергались дальнейшей обработке или были разведены в противополож- 
ные стороны (рис. 3: Б), и фрагменты пластин с завернутой кромкой для фальиевого соединения (рис. 3/В). Очевидно, детали будущих котлов выкраивались со значительным припуском, и после их чернового соединения излишки отрезались. Обрезки либо выбрасывались, о чем свидетельствует насыщенность ими культурного слоя в пределах мастерской, или собирались для последующей переработки. В одной из ям, разобранной в восточной части мастерской (№ 7), зафиксированы остатки прямоугольного деревянного ящикка, где содержались металлические отходы (обрезки пластин, капли, сплески металла и пр.) (рис. 1), мощность этого скопления составляла 25-30 см. Очевидно, металл собирали для последующей переработки.

Далее собранная заготовка котла снабжалась ушками и дужкой. В мастерской найдены литые ушки котлов (рис. 4: А), отдельные их экземпляры не завершены (рис. 4: А: 3), некоторые - бракованные, что свидетельствует о том, что медник сам занимался и изготовлением литых элементов котлов.

Ушки прикреплялись к котлам путем клепки. Особенностью обнаруженной мастерской является наличие в ней большого количества заклепок из пластин на всех стадиях изготовления, начиная от заготовок и заканчивая фрагментами готовых изделий с клепками (Крыласова, Подосенова, 2020), которых за два года раскопок обнаружено более 1,5 сотен. Заготовками служили пластины ромбической формы размерами 12-18Ч18-25 мм (рис. 4: Б: 1-14). Их сворачивали конусом так, что две стороны ромбической пластины, смыкающиеся в одном углу, сводились друг к другу, заводились немного внахлест (свертка «фунтиком») и проковывались. В результате формировался пустотелый гвоздь, в верхней части получившегося конуса оставался треугольный выступ (рис.4/Б: 15-29), из которого на следующем этапе формировалась шляпка. На всех проанализированных заклепках края шляпки прилегают друг к другу очень плотно, что свидетельствует о ее формировании на твердой основе (рис. 4: Б: 33-53). Вероятно, использовалось нехитрое приспособление, напоминающее гвоздильню: брусок из твердых материалов с коническими гнездами, разными по диаметру и глубине. Полуфабрикат заклепки помещали в одно из гнезд, уголок загибали так, что над конусом образовывалась своеобразная «крышечка»: угол треугольного выступа сводился к месту соединения боковых сторон на верхнем краю конуса, а затем проковывали кузнечным молотком. Шляпки заклепок имеют достаточно стандартную овально-миндалевидную форму, на них прослеживается тонкий след загнутого и раскованного уголка.

Многочисленные заклепки, бывшие в употреблении, сохранившиеся как отдельно (рис. 4: Б: 54-70), так и на фрагментах медных пластин, позволяют реконструировать процесс клепки. В пластинах (или стенках котлов) предварительно с помощью бородков пробивались отверстия по диаметру стержня заклепки. Заклепка помещалась в отверстие с лицевой стороны, с изнаночной стороны проводилась расклепка его конического острия. Мягкая структура пластинчатого острия позволяла расклепать его так, чтобы обеспечить наиболее плотное примыкание соединяемых пластин. Дополнительную надежность клепке обеспечивали шайбы в виде сравнительно небольших пластин округлой, полуовальной или подпрямоугольной формы (рис. 5: А: 1-9).

Готовые котлы снабжались дужками, с помощью которых они подвешивались над огнем. Дужки с помощью петель закреплялись в ушках. Обычно котлы, встречающиеся на средневековых памятниках Пермского Предуралья (не только медные, но и подражающие им керамические) снабжались железными дужками, отдельные фрагменты которых были обнаружены и в пределах рассматриваемой мастерской. Но здесь найдена также литая бронзовая дужка (рис. 4: А: 10), вероятно, предназначенная для какого-то более парадного котла.

О том, что кроме изготовления медной посуды мастер специализировался и на ее ремонте, свидетельствуют находки многочисленных медных заплат. Они имеют разные размеры, обусловленные площадью повреждения, и по форме преимущественно представляют собой прямоугольник со срезанными углами (рис. 5: А: 10-17).

Для ремонта могли использоваться и пластинчатые заклепки иного типа, чем описанные выше, которых собрана значительная серия (рис. 4: В). Заготовки для этих заклепок также имели форму ромба, только сильно вытянутого по бокам. При изготовлении заклепки длинные заостренные концы сначала отгибались к центру таким образом, чтобы образовалась примерно прямоугольная заплатка. На осевой линии заклепки эти концы вновь сгибались, пропускались в трещину на ремонтируемом предмете, затем разводились 


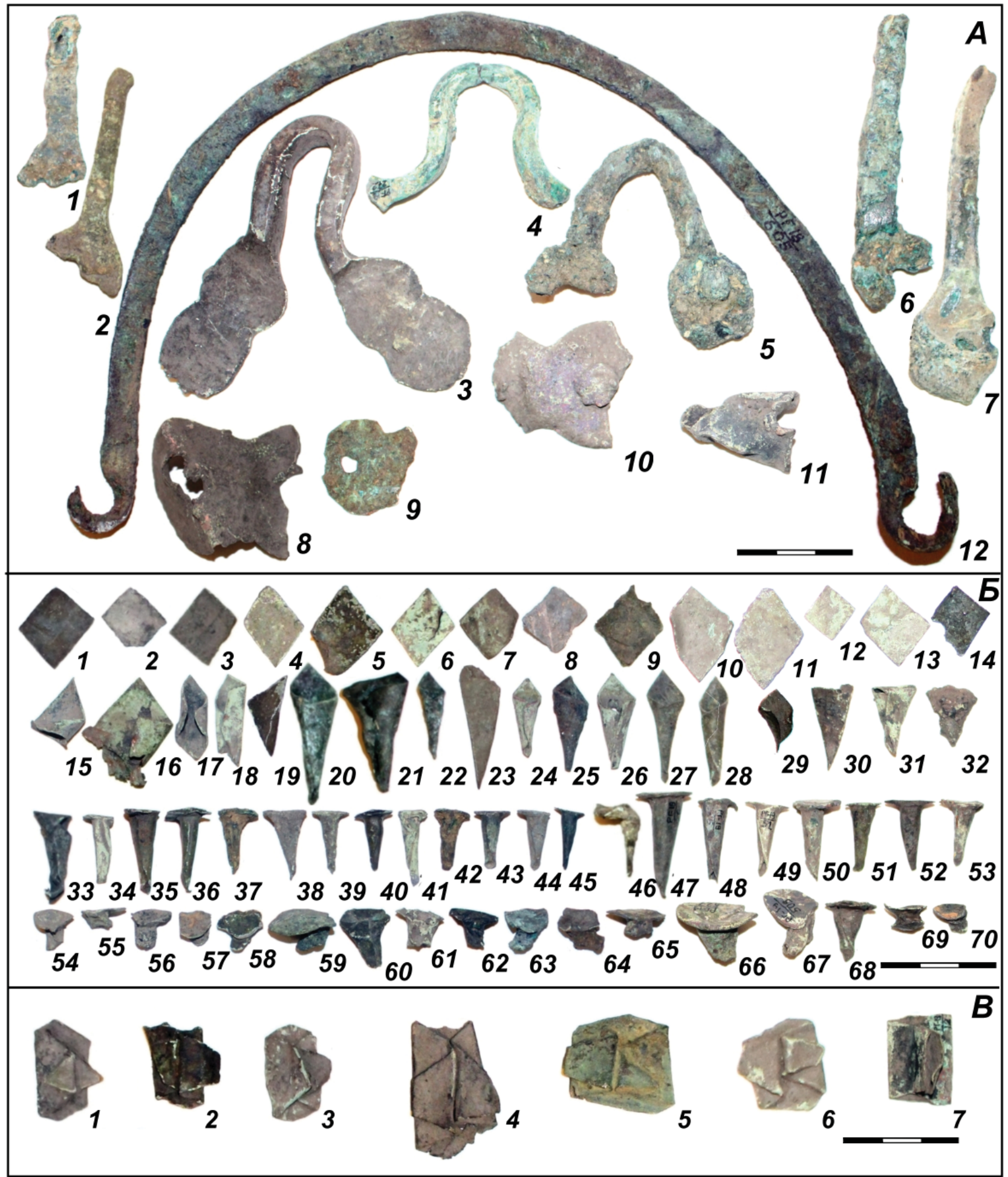

Рис. 4. А - литые ушки (1-9) и дужка (10) котлов; Б - примеры заготовок, полуфабрикатов и использованных пластинчатых заклепок-гвоздиков; В - пластинчатые заклепки-заплатки

Fig. 4. A - cast ears (1-9) and bow (10) of boilers; Б - examples of blanks, semi-finished products and used plate rivets (studs); B - plate rivets (patches)

в стороны и расковывались. Таким образом, подобные заклепки одновременно служили заплатками.

Кроме посуды в мастерской производились и другие изделия из медных пластин. В частности, здесь обнаружено несколько медных кружкков, использовавшихся в качестве подложек монетовидных подвесок или медальонов, а также фрагменты пластин, из которых их вырезали (рис. 5: Б). Имеется также серия медных обойм, которые применялись для оформления венчиков деревянных сосудов и краев кожаных кошельков (рис. 5: В).

Медник занимался и изготовлением проволоки, о чем свидетельствует большое количество заготовок в виде узких полос, нарезан- 


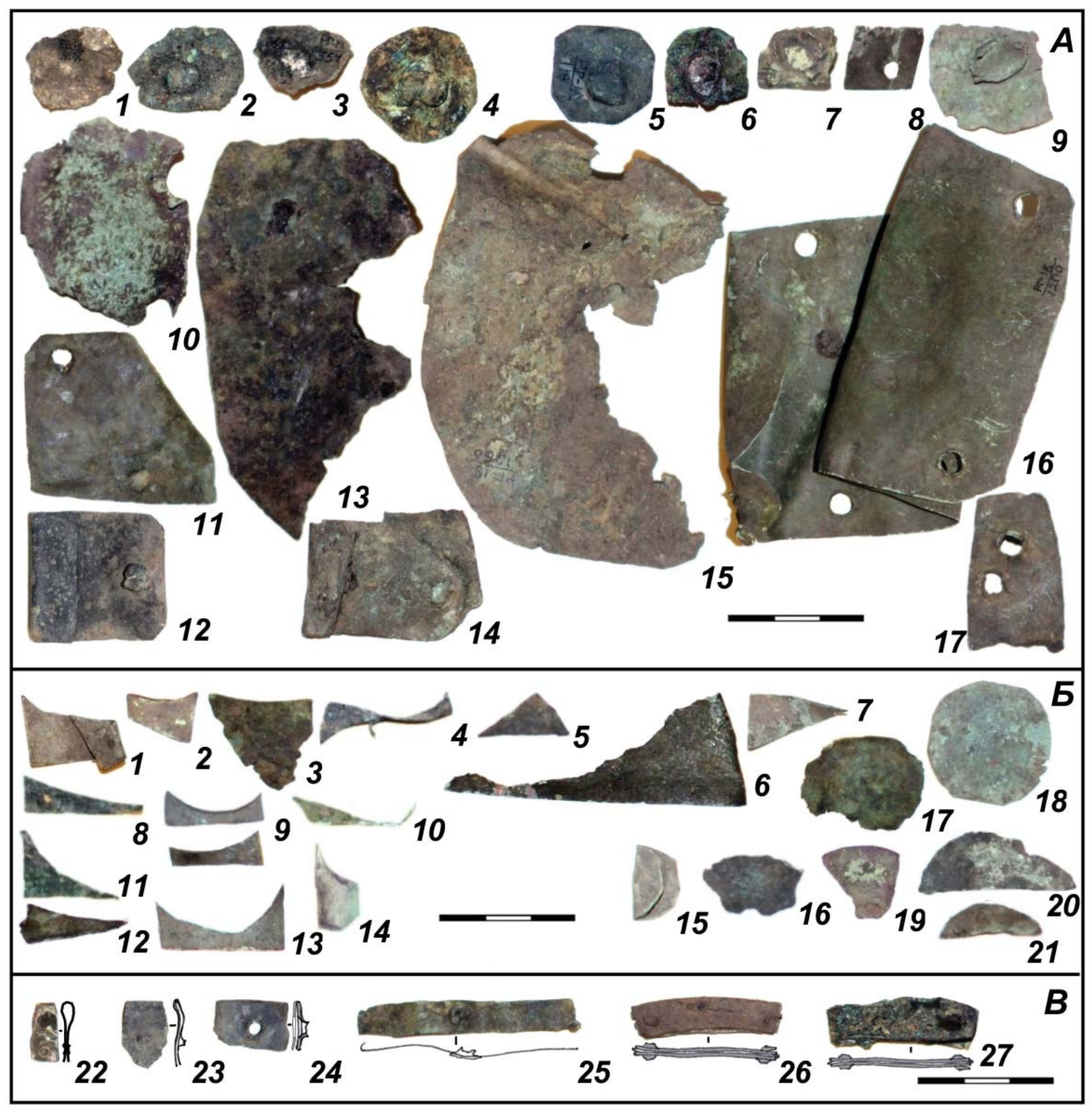

Рис. 5. А - шайбы (1-9) и заплаты (10-17); Б - медные подложки монетовидных подвесок (15-21) и обрезки пластин, из которых их вырезали (1-14); В - обоймы и обкладки краев кошельков

Fig. 5. A - washers (1-9) and patches (10-17); Б - copper substrates of coin-shaped pendants (15-21) and trimming of the plates which they were cut of (1-14); B - clips and edges of purses

ных из медных пластин (рис. 6: А), иногда даже в виде мотков (рис. 6: Б). Хотя некоторые из этих пластин могли использоваться в качестве прокладок в венчиках котлов.

Судя по имеющимся материалам, проволока могла изготавливаться двумя способами. В первом случае металлические ленточки или сворачивались в трубочку, или закручивались вдоль оси. Затем из ленточки формировалась проволока - холодной плоской прокаткой или протягиванием через грубую фильеру. Такая техника закручивания использовалась примерно до 1000 года нашей эры (Pops, 2009, c. 140-141). О возможном применении этого архаичного способа свидетельствует находка ленточки, свернутой спиралью в трубочку (рис. 6: В: 1). При другом способе металлические полоски непосредственно протягивались через фильеры из натуральных камней с отверстиями или из металлов, таких как медь или железо. После одной-двух протяжек через фильеру ленточки превращались в трубочки. Из этих трубочек затем формировалась круглая проволока протягиванием за один-два прохода через отверстие нужного диаметра (Pops, 2009, с. 141). Как известно, в Средневековье для изготовления проволоки начали применять волочильную доску, в кото- 


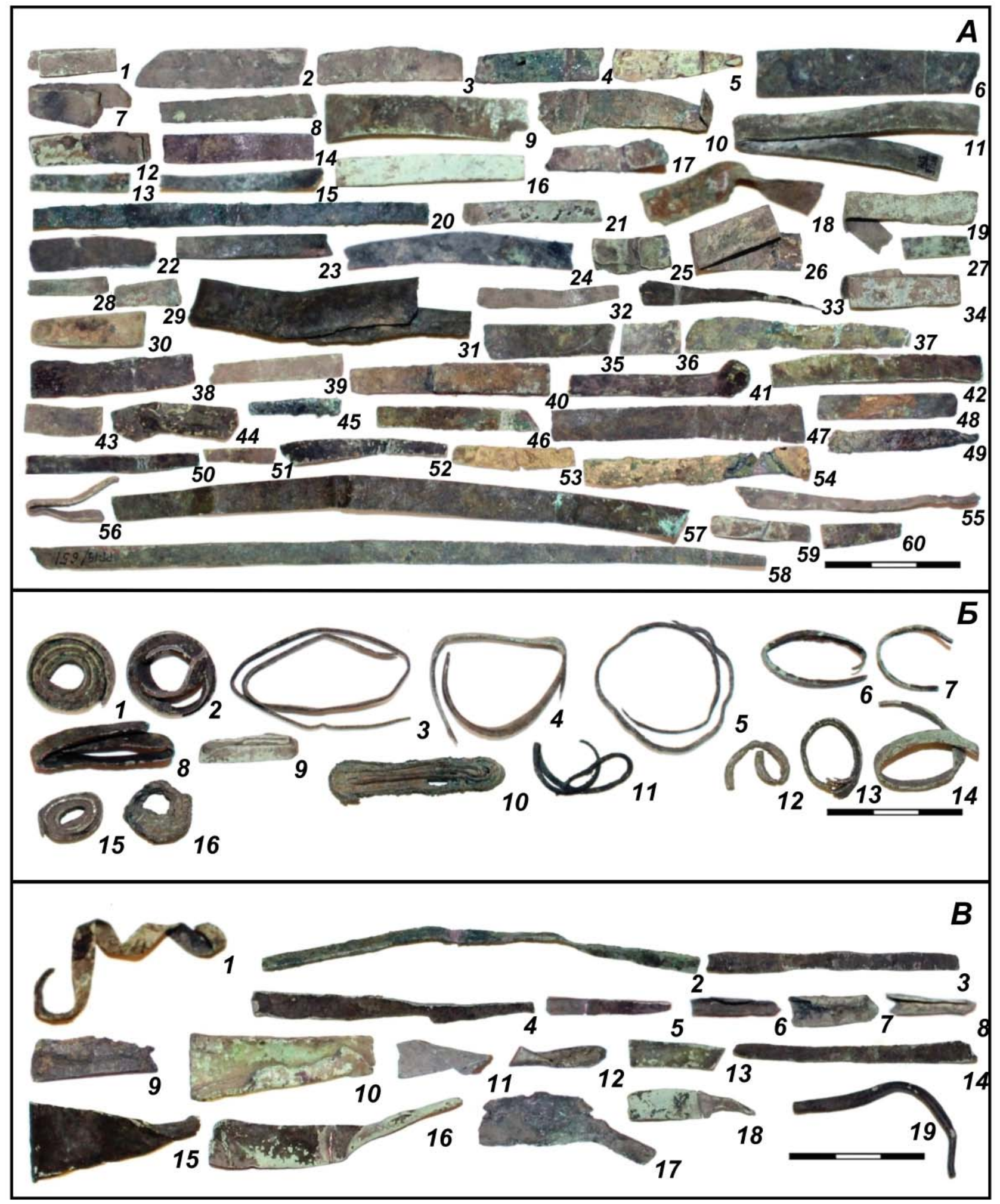

Рис. 6. А - фрагменты медных полос; Б - мотки медных лент и проволоки; В - отходы производства проволоки Fig. 6. A - fragments of copper strips; Б - coils of copper tapes and wire; B - wire production waste

рой был сделан ряд отверстий с постепенно уменьшающимся диаметром для того, чтобы при протягивании проволоки через них постепенно уменьшать ее диаметр до нужной величины (Pops, 2009, с. 141). Свидетельств такого способа получения проволоки в коллекции значительно больше - имеются фрагменты ленточек, свернутых в трубочку (рис. 6: В:
2-14), а также фрагменты, у которых один конец скручен в трубочку и частично протянут через фильеру (рис. 6: В: 15-19), очевидно, полученный полуфабрикат проволоки был отрезан, а остаток не протянутой через фильеру пластины выброшен.

О том, что мастер занимался и тиснением, свидетельствует находка в мастерской желез- 


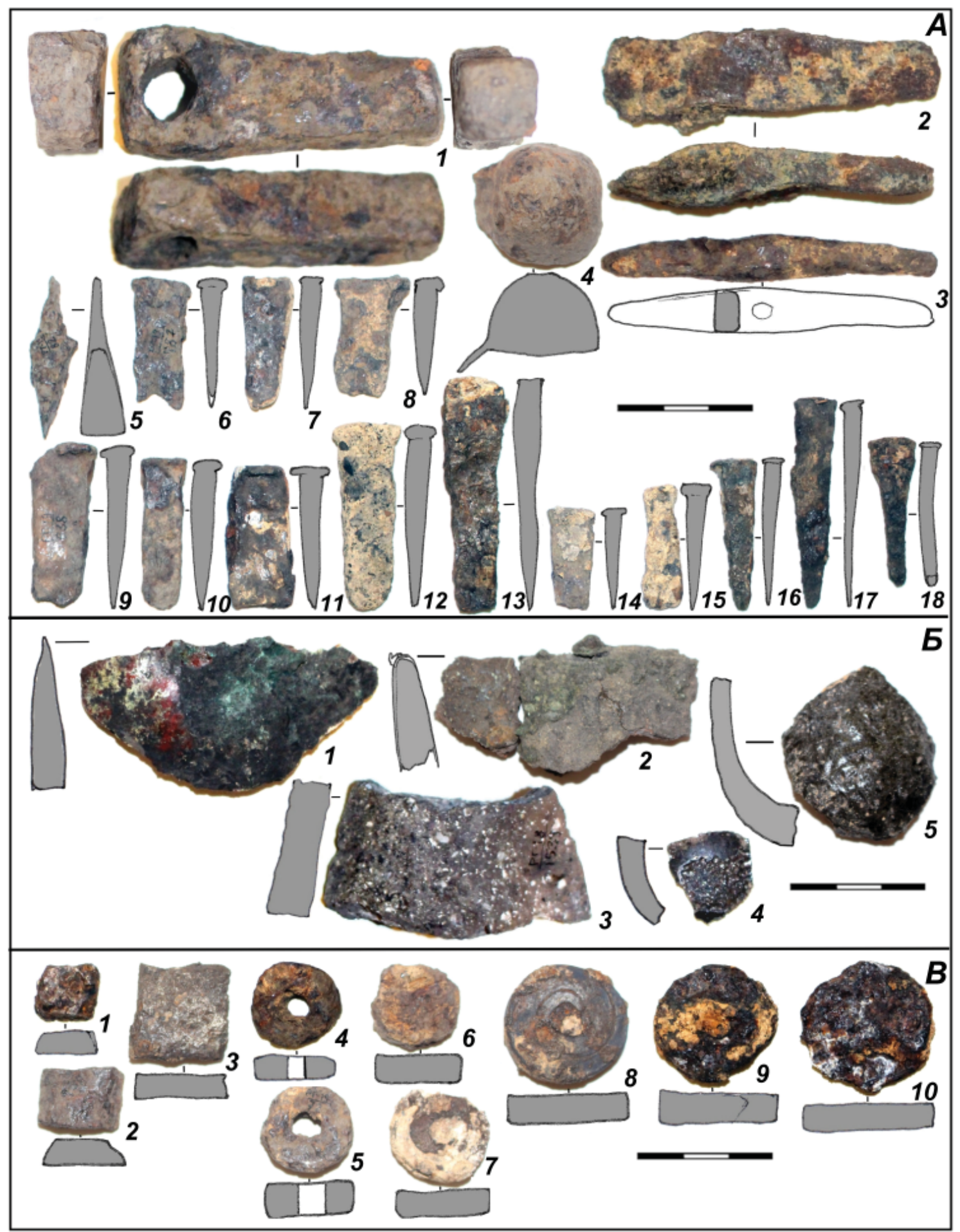

Рис. 7. А - медницкие и кузнечные инструменты (железо): 1-3 - молотки, 4 - матрица, 5-15 - примеры зубил, 16-18 - примеры бородков; Б - фрагменты тиглей (глина); В - весовые гирьки (железо)

Fig. 7. A - copper and blacksmith tools (iron): 1-3 - hammers, 4 - matrix, 5-15 - examples of chisels, 16-18 - examples of barbs; B - fragments of melting pots (clay); B - weights (iron)

ной матрицьь для изготовления тисненых половинок бус (рис. 7: А: 4).

В мастерской медника обнаружено и значительное количество предметов, связанных с кузнечнылм производством, имеющим много общего с медницким делом. Наиболее массовую категорию из них составляли металлические конгломераты (70 экз.) - как целые, так и обрубленные сегменты - округлые «лепешки» с одной выпуклой стороной, представляющие собой остатки со дна горна, содержащие шлак со значительной примесью железа. Представлены также кузнечные заготовки, фрагменты стержней и прутков, куски железной проволоки и разнообразный лом.

Из инструментов, которые могли быть связаны как с медницким, так и с кузнечным производством, представлены миниатюрные 


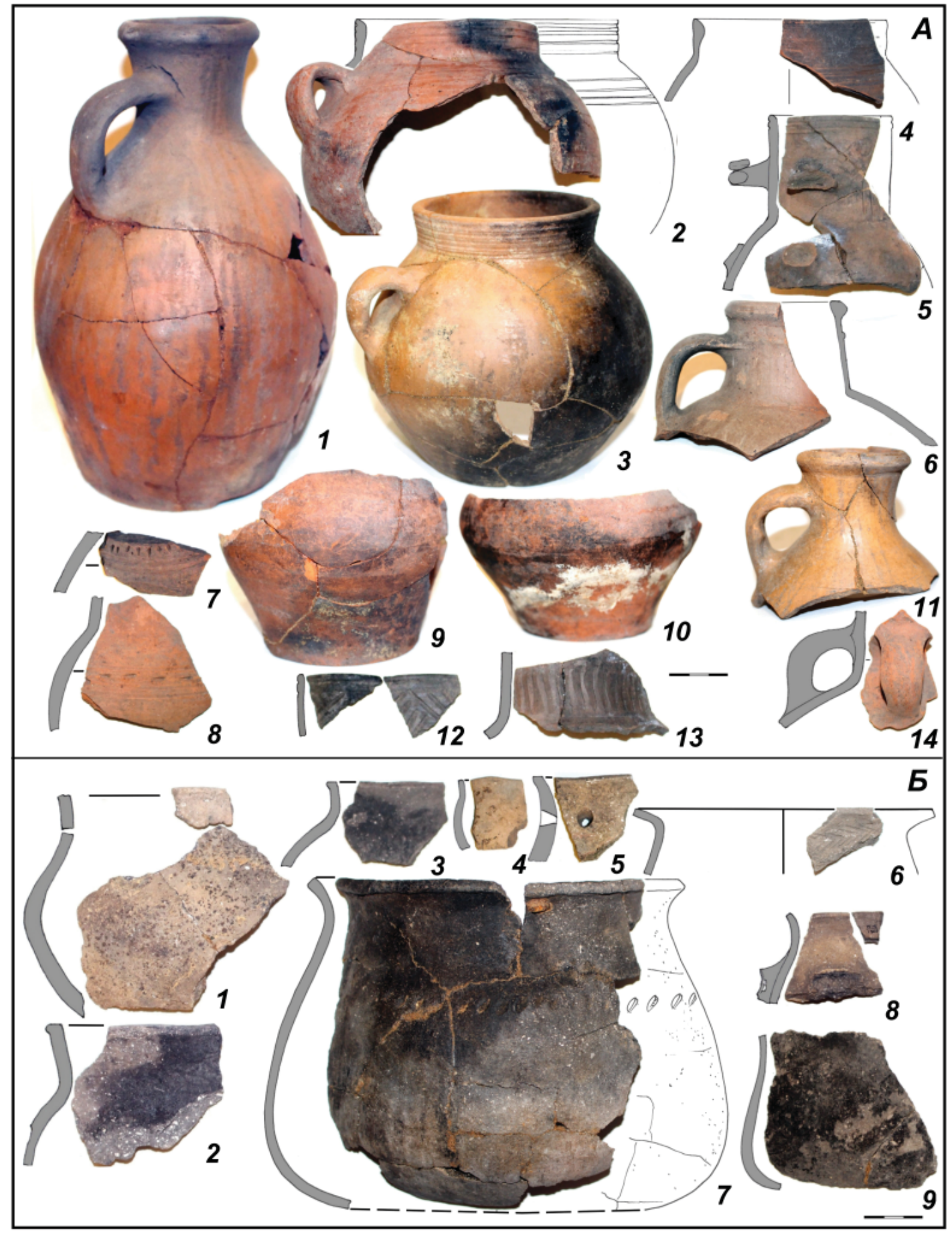

Рис. 8. А - примеры гончарной посуды булгарского производства;

Б - примеры лепной посуды местного производства

Fig. 8. A - examples of pottery of Bolgar manufacture;

$\mathrm{B}$ - examples of locally manufactured handmade ceramics

молоточки (рис. 7: А: 1-3), небольшие зубила (рис. 7: А: 5-15) и бородки (рис. 7: А: 16-18). Для финальной обработки металлических изделий, а также для заточки инструментов как бытового, так и производственного назначения могли использоваться каменные осел$\kappa u$, концентрация которых в мастерской была значительно выше, чем на других участках городища. К предметам, связанным с литейным производством, принадлежат фрагменты глиняных тиглей (рис. 7: Б). Обращает на себя внимание наличие большого количества разновесов (рис. 7: В). Весовые гирьки, вероятно, использовались при взвешивании порций металла, необходимых для производственного процесса.

Конечно, ассортимент ремесленных инструментов должен был быть значительно шире. Но, как показывают наблюдения, мастерские на Рождественском городище оставлялись не второпях, ремесленники тщательно собирали все специализированные 
инструменты. А на языческом Рождественском могильнике, сопровождавшем городище, в ряде мужских погребений обнаружены ремесленные инструменты (Белавин, Крыласова, 2017), в том числе такие, которые могли использоваться в медницком деле: молотки, ножниць по металлу, шабер, фрагмент наковальни и пр.

В пределах мастерской наблюдалась высокая концентрация булгарской керамики. В целом по раскопу VIII количество булгарской керамики составляет 46,5\%, что в среднем соответствует еe соотношению на других участках памятника, где гончарная керамика булгарского производства составляет от 27 до $65 \%$. Но в медницкой мастерской количество булгарской керамики достигало 60\%, в том числе в ямах 4 и 10 обнаружены развалы сосудов полных форм (рис. 8: А). На основании этого можно предположить, что ремесленник, работавший в мастерской, был выходцем из Волжской Булгарии.

Отчасти о булгарской принадлежности мастера могут свидетельствовать некоторые бытовые вещи, встреченные в мастерской. В частности, здесь найдена костяная трубка (рис. 9: A: 1) - в Волжской Булгарии такие предметы, иногда с орнаментом и отверстием для шнура или пробки, широко использовались в качестве игольников (Руденко, 2005, с. 71), в то время как в Прикамье функцию игольников обычно выполняли металлические флаконовидные пронизки (Крыласова, Подосенова, 2018). Нетипичными для местного финно-угорского населения, которое предпочитало использовать Т-образые рукояти шильев (Крыласова, 2007, с. 233-235), были прямые костяные рукояти шильев (рис. 9: А: 2). Найденные в мастерской железные шилья с острием квадратного сечения и прямоугольным в сечении черешком в большинстве случаев имеют четко выраженный уступ в месте перехода к острию (рис. 9: Б: 4-5), что характерно для булгарских шильев (Культура Биляра, 1985, с. 61). От булгар в Предуралье с XII в. начали проникать миндалевидные костяные навершия на деревянные рукояти ножей (рис. 9: А: 3), которые были распространены как в домонгольский, так и в золотоордынский период (Руденко, 2005, c. 73). Вероятно, булгарское происхождение имеют железные набойки каблуков (рис. 9: Б: 1-2). Несомненно, булгарским является серебряный перстень XI-XIII вв. (рис. 10: А: 2) с рисунком в виде диагонального креста из переплетенных овалов, на боковых сторонах
- рисунок в виде треугольника с вписанным в него трилистником (Руденко, 2010, с. 14). На подобных перстнях, массово производимых в Предуралье в подражание булгарским, обычно отсутствует линейное обрамление по краям щитка, орнамент на шинке - в виде трех треугольников (Моряхина, 2020, с. 18).

Отдельно хотелось бы упомянуть набор из астрагалов мелкого рогатого скота с отверстиями или со следами обработки (рис. 9: А: 6-11), которые использовались как игральные фишки и биты. Такие предметы нельзя отнести к числу массовых находок на Рождественском городище. Как правило, их находки тяготеют к ремесленным мастерским, на основании чего можно предположить, что игра в кости была характерна для субкультуры ремесленников. Как отмечает К.А. Руденко, использование бараньих астрагалов для игры является преимущественно тюркской традицией (Руденко, 2005, с. 74).

Для датировки мастерской наиболее значимыми являются радиоуглеродные даты. Все пробы угля для анализа, проведенного в лаборатории ИИМК РАН, отбирались из ям, где не было сомнения в том, что слой перемешан. В целом получено пять $\mathrm{AMS}{ }^{14} \mathrm{C}$ датировок. Календарный возраст образцов угля с вероятностью $2 \sigma(95,4 \%)$ из ямы 4 определен в интервале 990-1170 кал. л. н. э. (Ле-11862, OxCal v 3.10), из ямы 6 - в интервале 12151280 кал. л. н. э. (Ле-11864, OxCal v 3.10), из ямы 7 - в интервале 960-1160 кал. л. н. э. (Ле-12035, OxCal v 3.10), из ямы 8 - в интервале 1040-1280 кал. л. н. э. (Ле-12034, OxCal v 3.10) и из ямы 11 - в интервале 880-1160 кал. л. н. э. (Ле-12037, OxCal v 3.10). Таким образом, представленные даты охватывают почти весь период существования Рождественского городища. Но на Рождественском городище отчетливо прослеживается, что новые ямы обычно сооружались на месте старых, связанных с предыдущими постройками, по стратиграфии видно, что они перестраивались порой до пяти раз. И наличие ранних дат объясняется принадлежностью их к слоям более ранних построек.

По анализу вещевого инвентаря, собранного в слоях мастерской, ее можно датировать XII-XIII вв. Этому периоду соответствует местная лепная керамическая посуда, среди которой представлены и наиболее характерные для данного периода сосуды «кошелевидной» формьл (рис. 8: Б: 6-9).

Из бытовых предметов для датировки сооружения может служить овальное двулез- 


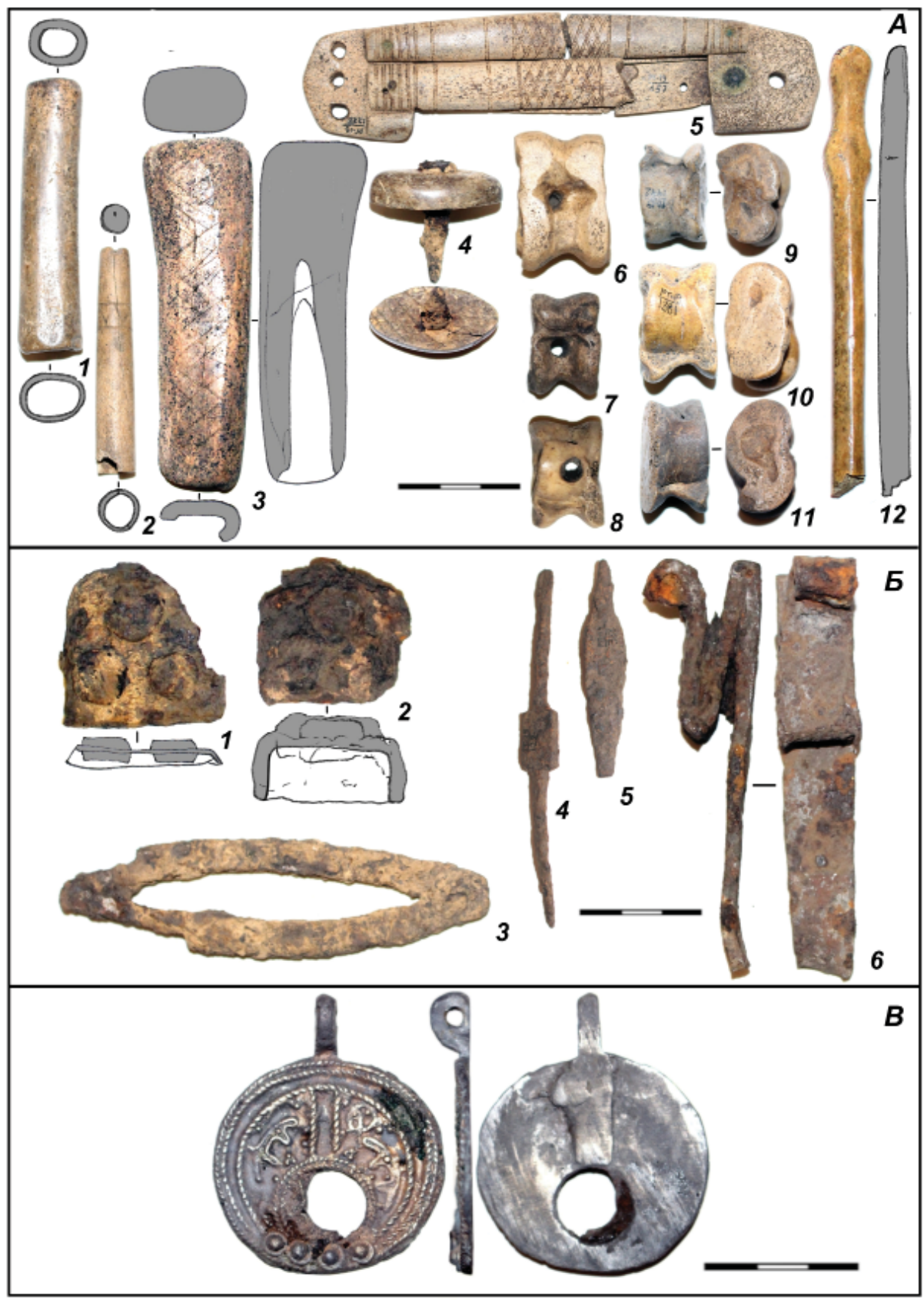

Рис. 9. А - предметы быта из кости и рога: 1 - игольник, 2 - рукоять шила, 3 - рукоять ножа, 4 - затыльник рукояти ножа, 5 - футляр расчески, 6-11 - альчики из таранных костей мелкого рогатого скота, 12 - фрагмент

стилоса; Б - предметы быта из железа: 1-2 - набойки каблуков; 3 - кресало, 4-5 - шилья, 6 - светец;

В - бронзовая подвеска-лунница

Fig. 9. A - household items made of bone and horn: 1 - needlecase, 2 - awl handle, 3 - knife handle, 4 - back of a knife handle, 5 - comb case, 6-11 - playing dice made of talus bones of small cattle, 12 - fragment of a stylus; 5 - household items made of iron: 1-2 - heel pads; 3 - steel, 4-5 - awls, 6 - torch holder; B - bronze pendant- lunula

вийное кресало ХІ-ХІІІ вв. (рис. 9: Б: 3) (Крыласова, 2007, с. 142-143, рис. 61), костяной футляр составной расчески XI-XII вв. (рис. 9/А: 5) (Крыласова, 2007, с. 271-275), а особенно интересен железный светеи (рис. 9/Б: 6), обнаруженный у южной стены мастерской - светцы на территории Пермского края появляются не ранее XIII-XIV вв. (Крыласова, 2007, с. 196-197, рис. 86).

XII-XIII веками датируется подавляющее большинство металлических украше- ний, найденных в мастерской. Не вдаваясь в детальную характеристику всей их совокупности, остановимся лишь на наиболее выразительных находках.

Среди металлического лома, сконцентрированного у ямы 7 , был найден квадратный серебряный каст для вставки, обрамленный зернью и торсированной проволокой (рис. 10: А: 1), такие касты использовались в составе прикамских ювелирных украшений XII-XIV вв. 


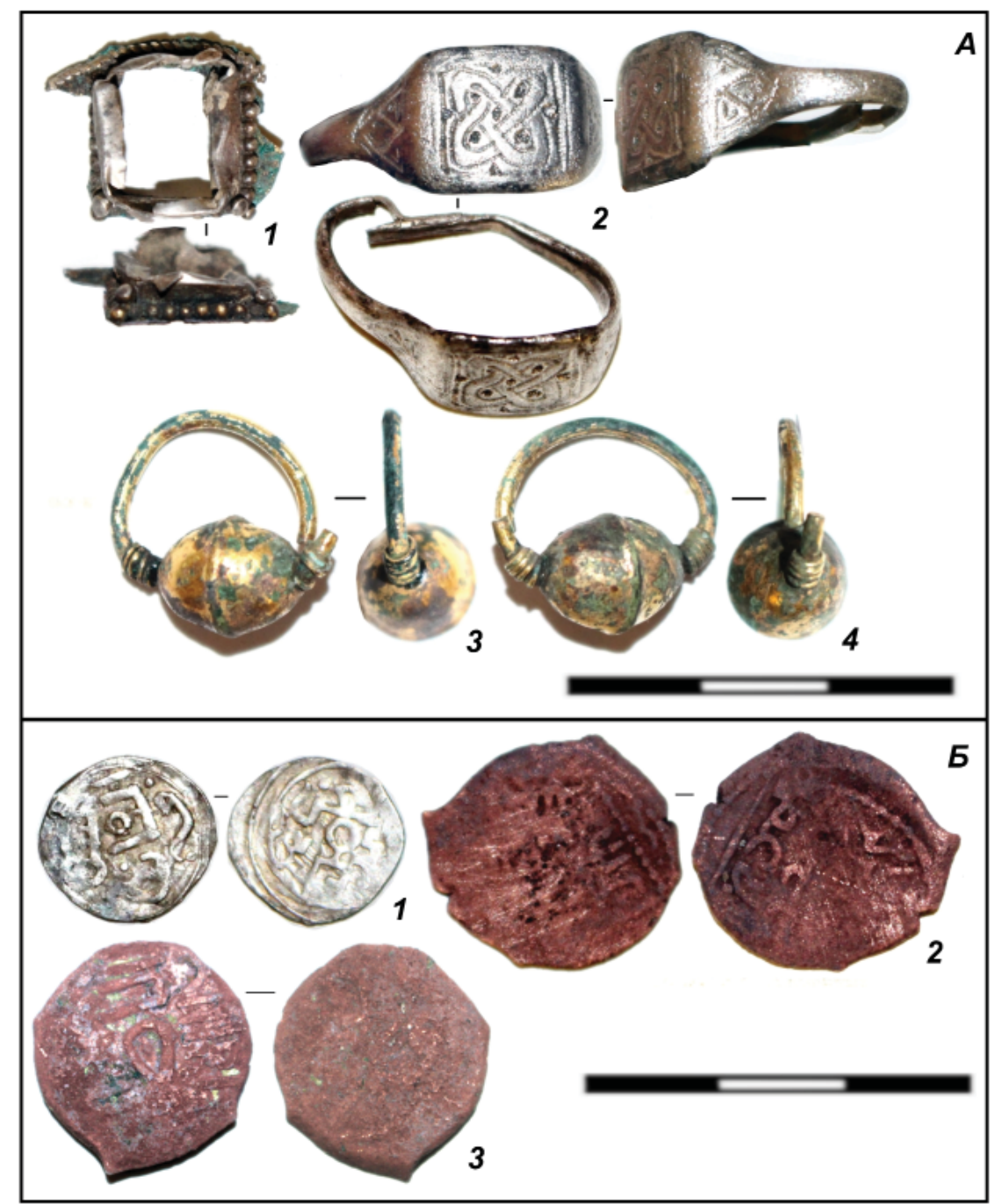

Рис. 10. А - украшения: 1 - серебряный каст, 2 - серебряный перстень, 3-4 - серьги медные с позолотой; Б - монеты: 1 - серебро, 2-3 - медь

Fig. 10. A - jewelry: 1 - silver holder, 2 - silver ring, 3-4 - copper earrings with gilding; Б - coins: 1 - silver, 2-3 - copper

К числу наиболее ярких находок принадлежит подвеска-лунница (рис. 9: В), найденная возле ямы 4. Она отлита из оловянно-свинцовой бронзы по оттиску ювелирного изделия с зерно-сканым декором, в оформлении которого прослеживаются черты, характерные для прикамских замкнутых лунниц XII-XIII вв.: двойные ряды скани по внешнему контуру изделий и выкладка сканью контуров внутреннего отверстия, ряд крупных зерен, обрамленных сканью, под внутренним отверстием, разделение орнаментального поля двумя вертикальными рядами скани. По бокам от вертикальных рядов скани прослеживаются контурные изображения животных, что делает подвеску уникальной: слева - изображение лося, справа - пушной зверь семейства куньих и круг (солярный символ) с крестовидной фигурой внутри. Присутствие в оформлении лунницы изображений животных и солярного знака сближают ее с известной серией медальонов «с охотничьим сюжетом», среди которых имеются и замкнутые лунницы (Крыласова, Подосенова, 2018а).

Любопытной находкой является napa небольших медных позолоченных сережек с одной гладкой напускной бусиной (рис. 10: А: 3-4), найденных в яме 11. Прямых аналогий им пока не выявлено. На основе отдельных технологических особенностей серьги можно датировать XIII-XIV вв.: фиксация бусин на проволочной основе с помощью обмотки распространилась не ранее XI в., обмотка проволочной основы гладкой проволочкой характерна для золотоордынских изделий XIII-XIV вв., распространение приема нанесения позолоты на изделия с помощью плакинирования наблюдается в XII-XIV вв. (Подосенова, 2021, с. 128).

В яме 11 был найден обломок костяного стилоса с характерной заполированностью рукояти округлого сечения и с затертой 
«лопаточкой» на тыльной стороне, предназначенной для стирания написанного на воске. По классификации Б.Б. Овчинниковой, этот стилос можно отнести к типу 15 , датированному по новгородским аналогиям серединой XIII-XVI вв. (Овчинникова, с. 58-59, рис. $13 / 4,9)$.

Ну и разумеется, для датировки мастерской важным источником являются монетbl, подтверждающие тот факт, что финальный этап функционирования мастерской приходится на золотоордынский период второй половины XIII века:

серебряная монета (рис. 10: Б: 1) - Джучиды, анонимный данг с тамгой Менгу-Тимура, вторая половина 1270-х гг., Сарай;

медная монета (рис. 10: Б: 2) - Чингизиды, Мунке (Mцngke, 1251-1259), Булгар;

медная монета неправильной формы (рис. 10/Б: 3) - улус Джучидов, с «очковидной» тамгой, конец XIII в. (определение Вяч.С. Кулешова).

Подводя итог, отметим, что обнаруженная и исследованная на Рождественском горо- дище медницкая мастерская - это значимое открытие не только для средневековой археологии Пермского Предуралья, поскольку медная посуда и иные изделия из медных пластин имели чрезвычайно широкое распространение, а полученные данные в значительной степени позволяют расширить представления об особенностях медницкого производства. Возвращаясь к приведенному в начале статьи предположению Ф.Ш. Хузина о переселении булгарских ремесленников по Камскому торговому пути, отметим, что описанная мастерская является ярким примером этому. Предположительно ремесленник, основавший мастерскую, переселился из Волжской Булгарии. Здесь он обзавелся семьей и подмастерьями, его дети и ученики долгое время обеспечивали функционирование медницкой мастерской. Анализ культурных напластований в ее пределах, содержащих следы перестройки и ремонта, позволяет предполагать, что мастерская вполне могла существовать более 100 лет.

\section{ЛИТЕРАТУРА}

Белавин А.М. Камский торговый путь из Болгара «в страну Вису и Чулыман» // Международные связи, торговые пути и города Среднего Поволжья в IX-XIII веков. Материалы Международного симпозиума Казань, 8-10 сентября 1998 г. / Отв. ред. Ф.Ш. Хузин. Казань: ИИ АНТ, 1999. С. 161-173.

Белавин А.М. Камский торговый путь. Средневековое Предуралье в его экономических и этнокультурных связях. Пермь: ПГПУ, 2000. 200 с.

Белавин А.М. О социально-экономических критериях выделения протогородов у коренных народов Урало-Поволжья // Труды Камской археолого-этнографической экспедиции. Вып. I-II / Отв. ред. А.М. Белавин. Пермь: ПГПУ, 2001. С. 108-110.

Белавин А.М. Вопросы ранней урбанизации в средневековом финно- угорском мире по данным археологии // Труды Камской археолого-этнографической экспедиции. Вып. XV. / Отв. ред. А.М. Белавин. Пермь: ПГГПУ, 2019. С. 117-127.

Белавин А.М., Крыласова Н.Б. Основные итоги изучения Рождественского археологического комплекса (город Афкула) в Пермском крае // Научный Татарстан. 2009. № 2. С. 6-20.

Белавин А.М., Крыласова Н.Б. Касаба Афкула в письменных источниках и в археологической реальности Вопросы интеграции археологических и исторических исследований Материалы Всероссийской (с международным участием) археологической конференции (Астрахань, 29 сентября - 01 октября 2017 г.) / Отв. ред. Д.В. Васильев. Астрахань: Изд-ль Сорокин Роман Васильевич, 2017. С. 3-10.

Белавин А.М., Крыласова Н.Б. Ювелирные инструменты средневекового населения Предуралья (по материалам Рождественского археологического комплекса) // Препринт научного доклада на международной конференции «Археология Арктики», 19-22 ноября 2017 г., г. Салехард, Россия; Перм. гос. гуманит.-пед. ун-т. Пермь, 2017. 19 с.

Крыласова Н.Б. Археология повседневности: материальная культура средневекового Предуралья. Пермь: ПГПУ, 2007. 352 с.

Крыласова Н.Б. Керамическая посуда Рождественского городища. Раскоп VII 2008 г. // Труды Камской археолого-этнографической экспедиции. Университет и историко-культурное наследие региона. Вып. V. / Отв. ред. А.М. Белавин. Пермь:: ПГПУ, 2008. С. 139-147.

Крыласова Н.Б., Подосёнова Ю.А. Флаконовидные пронизки на территории Пермского Предуралья в эпоху средневековья // Вестник Пермского научного центра. 2018. № 2. С. 49-60.

Крыласова Н.Б., Подосёнова Ю.А. Лунница из Рождественского городища // Вестник Музея археологии и этнографии Пермского Предуралья. 2018а. Вып. VIII. С. 31-35. 
Крыласова Н.Б., Подосёнова Ю.А. Медницкое дело в средневековом городке (по материалам раскопок 2018 года на Рождественском городище) // Вестник Пермского университета. История. 2020. № 1 (48). C. $62-70$.

Культура Биляра. Булгарские орудия труда и оружие X-XIII вв. / Отв. ред. А.Х. Халиков. М.: Наука, 1985. $216 \mathrm{c}$.

Кузьминых С.В., Семыкин Ю.А. Цветная металлообработка // История Татар с древнейших времен. Т.ІІ. Волжская Булгария и Великая Степь. / Отв. ред. Ф.Ш. Хузин. Казань: Изд-во РухИЛ, 2006. C. $258-271$.

Моряхина К.В. Контакты населения Пермского Предуралья и Волжской Булгарии (по материалам украшений рук) // Труды Камской археолого-этнографической экспедиции. Вып. XVI. / Отв. ред. А.М. Белавин. Пермь: ПГГПУ, 2020. С. 15-20.

Овчинникова Б.Б. Писала-стилосы Древнего Новгорода X-XV вв.: (свод археологического источника) // Проблемы истории России. Вып. 3: Новгородская Русь: историческое пространство и культурное наследие. Екатеринбург, 2000. С.45-105.

Подосенова Ю.А. Височные украшения средневекового населения Пермского Предуралья. Пермь: Пггпу, ПФИЦ УрО РАН, 2021. 210 с.

Руденко К.A. Металлическая посуда Поволжья и Прикамья в VIII-XIV вв. Казань: Репер, 2000. 158 с.

Руденко К.A. Булгарские изделия из кости и рога // Древности Поволжья: эпоха средневековья (исследования культурного наследия Волжской Булгарии и Золотой Орды) / Отв. ред. К.А. Руденко. Казань: Школа, 2005. С. 67-97.

Руденко К.А. Булгарское черневое искусство: перстни. Казань: КГУКИ, 2010. 44 с.

Хузин Ф.Ш. Некоторые проблемы изучения Камского торгового пути // Камский торговый путь. Материалы II Всероссийской научно-практической конференции / Ред. Корнилова И. В. и др Набережные Челны: НГПУ, 2018. С. 48-56.

Pops H. Изготовление проволоки - из древности в будущее / пер. С.Юрьев // Компоненты и технологии. 2009. № 7. С. 140-146.

\section{Информация об авторе:}

Крыласова Наталья Борисовна, доктор исторических наук, главный научный сотрудник, Пермский федеральный исследовательский центр Уральского отделения Российской академии наук, професcop, Пермский государственный гуманитарно-педагогический университет (г. Пермь, Россия); n.krylasova@mail.ru

\section{REFERENCES}

Belavin, A. M. 1999. In Khuzin, F. Sh. (ed.). Mezhdunarodnye sviazi, torgovye puti i goroda Srednego Povolzh'ia IX -XII vekov (International Relations, Trade Routes and Cities from Middle Volga Region in the 9th-12th Centuries). Kazan: "Master-Line" Publ., 161-173 (in Russian).

Belavin, A. M. 2000. Kamskii torgovyi put'. Srednevekovoe Predural'e v ego ekonomicheskikh I etnokul'turnykh sviaziakh (Kama Trade Route: Medieval Cis-Urals in its Economic and Cultural Relations). Perm: Perm State Pedagogical University (in Russian).

Belavin, A. M. 2001. In Belavin, A. M. (ed.). Trudy Kamskoi arkheologo-etnograficheskoi ekspeditsii (Proceedings of the Kama Archaeological and Ethnographical Expedition) I-II. Perm: Perm State Humanitarian Pedagogical University, 108-110 (in Russian).

Belavin, A. M. 2019. In Belavin, A. M. (ed.). Trudy Kamskoi arkheologo-etnograficheskoi ekspeditsii (Proceedings of the Kama Archaeological and Ethnographical Expedition) XV. Perm: Perm State Humanitarian Pedagogical University, 117-127 (in Russian).

Belavin, A. M., Krylasova, N. B. 2009. In Nauchnyi Tatarstan (Scientific Tatarstan) (2), 6-20 (in Russian).

Belavin, A. M., Krylasova, N. B. 2017. In Vasil'ev, D. V. (ed.). Voprosy integratsii arkheologicheskikh $i$ istoricheskikh issledovanii. Materialy Vserossiiskoi (s mezhdunarodnym uchastiem) arkheologicheskoi konferentsii (Astrakhan, 29 sentiabria - 01 oktiabria 2017 g.) (Issues of the Integration of Archaeological and Historical Studies. Materials of the All-Russian (with international participation) Archaeological Conference (Astrakhan, September 29 - October 1, 2017). Astrakhan: "Sorokin Roman Vasil'evich" Publ., 3-10 (in Russian).

Belavin, A. M., Krylasova, N. B. 2017. Iuvelirnye instrumenty srednevekovogo naseleniia Predural'ia (po materialam Rozhdestvenskogo arheologicheskogo kompleksa) (Tools for Jewelry Production of the Medieval Population of the Cis-Urals (Based on Materials of Rozhdestvensk Archaeological Complex)). Perm: Perm State Humanitarian Pedagogical University (in Russian). 
Krulasova, N. B. 2006. Arkheologiia povsednevnosti: material'naia kul'tura srednevekovogo Predural'ia (Archaeology of Everyday Life: Material Culture of the Medieval Cis-Urals). Perm: Perm State Pedagogical University (in Russian).

Krulasova, N. B. 2008. In Belavin, A. M. (ed.). Trudy Kamskoi arkheologo-etnograficheskoi ekspeditsii (Proceedings of the Kama Archaeological and Ethnographical Expedition) 5. Perm: Perm State Humanitarian Pedagogical University, 139-147. (in Russian).

Krylasova, N. B., Podosenova, Yu. A. 2018. In Vestnik Permskogo Nauchnogo Tsentra (Bulletin of Perm Scientific Center) 2, 49-60 (in Russian).

Krylasova, N. B., Podosenova, Yu. A. 2018a. In Vestnik Muzeia arkheologii i etnografii Permskogo Predural'ia (Bulletin of the Museum of Archaeology and Ethnography of the Perm Cis-Urals) VIII, 31-35 (in Russian).

Krylasova, N. B., Podosenova, Yu. A. 2020. In Vestnik Permskogo universiteta. Seriia «Istoriia» (Bulletin of the Perm University. History Series) 48 (1), 62-70 (in Russian).

Khalikov, A. Kh. (ed.). 1985. Kul'tura Biliara. Bulgarskie orudiia truda i oruzhie X-XIII vv. (Culture of Bilyar. Bulgar Tools and Weapons in 10 $0^{\text {th }}-13^{\text {th }}$ Centuries). Moscow: "Nauka" Publ. (in Russian).

Kuz'minykh, S. V., Semykin, Yu. A. 2006. In Khuzin, F. Sh. (ed.). Istoriya tatar s drevnejshih vremen (v semi tomah) (History of the Tatars since ancient times (in seven volumes). 2 Kazan: "RukhIL" Publ., 258-271. (in Russian).

Moryakhina, K. V. 2020. In Belavin, A. M. (ed.). Trudy Kamskoi arkheologo-etnograficheskoi ekspeditsii (Proceedings of the Kama Archaeological and Ethnographical Expedition) XVI. Perm: Perm State Humanitarian Pedagogical University, 15-20 (in Russian).

Ovchinnikov, B. B. 2000. In Shashkov, A. T. (ed.). Novgorodskaia Rus': Istoricheskoe prostranstvo i kul'turnoe nasledie (Novgorod Rus: Historical Space and Cultural Heritage). Yekaterinburg: Ural State University, 45-105 (in Russian).

Podosenova, Yu. A. 2021. Visochnye ukrasheniia naseleniia Permskogo Predural'ia (Temple Ornaments of the Perm Cis-Urals Population). Perm: Perm State Humanitarian Pedagogical University, Perm Federal Research Center of the Ural Branch of the Russian Academy of Sciences (in Russian).

Rudenko, K. A. 2000. Metallicheskaia posuda Povolzh'ia i Prikam'ia v VIII-XIV vv. (Metal Dishware of Volga and Kama Regions in $8^{\text {th }}-14^{\text {th }}$ Centuries). Kazan: "Reper" Publ. (in Russian).

Rudenko, K. A. 2005. In Rudenko, K. A. (ed.). Drevnosti Povolzh'ia: epokha srednevekov'ia (issledovaniia kul'turnogo naslediia Volzhskoi Bulgarii i Zolotoi Ordy) (Antiquities of the Volga Region: the Medieval Period (Studies of the Cultural Heritage of Voga Bolgaria and the Golden Horde)). Kazan: "Shkola" Publ., 67-97 (in Russian).

Rudenko, K. A. 2010. Bulgarskoe chernevoe iskusstvo: perstni (Bolgar Metalworking Art: Rings). Kazan: Kazan State University for Culture and Arts (in Russian).

Khuzin, F. Sh. 2018. In Kornilova, I. V. et. (eds). Kamskii torgovyi put'(Kama Trade Route). Naberezhnye Chelny: Naberezhnye Chelny State Pedagogical University, 48-56 (in Russian).

Pops, H. 2009. In Komponenty i tekhnologii ((Components and Technologies) 7, 140-146 (in Russian).

\section{About the Author:}

Krylasova Natalia B. Doctor of Historical Sciences, Associate Professor. Perm State Humanitarian Pedagogical University. Sibirskaya Str., 24, Perm, 614990, Russian Federation. Perm Federal Research Center of the Ural Branch of the Russian Academy of Sciences. Lenina st., 13A, Perm, 614990, Russian Federation; n.krylasova@mail.ru 